\title{
Evaluation of C677T Polymorphism of the Methylenetetrahydrofolate Reductase (MTHFR) Gene in various Neurological Disorders
}

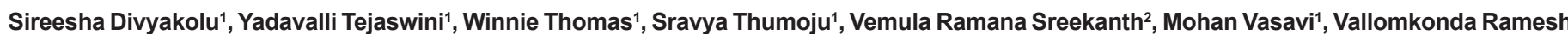
OmSai $^{3}$, Vallomkonda Nagaratna ${ }^{3}$, Qurratulain Hasan ${ }^{1,4}$ and Yog Raj Ahuja ${ }^{1 *}$

${ }^{1}$ Department of Genetics and Molecular Medicine, Vasavi Medical and Research Centre, Khairatabad, Hyderabad, India

${ }^{2}$ Department of Neurology, Apollo Hospital, Jubilee Hills, Hyderabad, India

${ }^{3}$ Department of Medical Sciences, National Institute of Mentally Handicapped (NIMH), Bowenpally, Hyderabad, India

${ }^{4}$ Department of Genetics and Molecular Medicine, Kamineni Hospital, LB Nagar, Hyderabad, India

\begin{abstract}
Background: Genetic risk factors play an important role in neurological disorders. In this case-control study, we examined the C677T polymorphism (rs1801133) in the Methylenetetrahydrofolate reductase (MTHFR) gene and its association with three neurodegenerative disorders: The late onset pathology, Alzheimer disease and two early onset ones, Autism and Down syndrome. New evidence suggests that autism may be associated with varied behavioural responses to folate therapy and metabolic anomalies, including those in folate metabolism, that contribute to hypomethylation of DNA. We hypothesis that, MTHFR C677T mutation may be the underlying common risk factor in various neurological disorders leading to impaired one carbon metabolism resulting in similar and severe neuropsychological symptoms. Hence our objective was to evaluate MTHFR C677T polymorphism in different Neurological disorders and compare it with age-matched healthy controls.
\end{abstract}

Method: This case-control study was carried out on 200 samples which included 100 patients with different neurological disorders and 100 healthy individuals without any neurological problems taken as the control group. MTHFR polymorphism was assessed by PCR-RFLP.

Results: Results indicated that the C677T MTHFR polymorphism was not significantly different between controls of younger and older age groups. Among the three neurological disorders studied the T allele was associated with autism ( $\mathrm{TT}+\mathrm{CT}$ vs. $\mathrm{CC}$; OR=4.472, 95\% Cl: 1.605-12.799, $\mathrm{p}<0.002)$, but not with the other two conditions.

Conclusion: In conclusion, despite the smaller sample size, the C677T polymorphism of MTHFR plays a role in some complex neurodevelopmental disorders and not in others.

Keywords: Alzheimer disease; Autism; Down syndrome; 5, 10-Methylenetetrahydrofolate Reductase; Polymorphism; Total homocysteine

Abbreviations: Alzheimer Disease: AD; Down Syndrome: DS; 5, 10-Methylenetetrahydrofolate Reductase (MTHFR); Total Homocysteine: T-Hcys

\section{Introduction}

Over the past few decades, various studies have shown an increased incidence of folate deficiency and a significant correlation with neuropsychological symptoms, especially cognitive decline, in psychogeriatric and psychiatric populations $[1,2]$. Both animal and human studies have shown the essential role of folate during nervous system and brain development [3]. Folates, especially in the form of methyl folate, are important for the nervous system at all ages. In vivo and in vitro studies suggest that chronic folate/methyl deficiency has been associated with abnormal DNA methylation [4-7].

Methylenetetrahydrofolate reductase (MTHFR) enzyme plays a key role in the folate metabolism pathway and regulates the intracellular folate pool for synthesis and methylation of DNA $[8,9]$. It catalyzes the conversion of 5,10-methylenetetrahydrofolate to 5-methyltetrahydrofolate, the methyl donor for the remethylation of homocysteine to methionine. The MTHFR gene is located at chromosome $1 \mathrm{p} 36.3$ and is $2.2 \mathrm{~kb}$ in length with a total of 11 exons [10]. Several single nucleotide polymorphisms in the MTHFR gene have been characterised, with C677T polymorphism being the most commonly studied [11]. The $\mathrm{C}$ to $\mathrm{T}$ mutation at position 677 causes an alanine to valine substitution in the MTHFR gene $(677 \mathrm{C} \rightarrow \mathrm{T})$ [12] which make the enzyme thermo-labile [13]. Reduced MTHFR activity raises the dietary requirement for folic acid, which is required to maintain normal homocysteine remethylation to methionine.

MTHFR C677T mutation has been associated with seizures, neurological impairment, and diabetic complications and has also been considered as a risk factor for birth defects and cancers [14-16]. Low blood levels of folate and vitamin B12, and elevated homocysteine levels were associated with poor cognitive performance in elderly people [2,17-20]. Insufficient one-carbon metabolism has been suggested to have a contributory role in the development of dementia and has been found to be significant in Alzheimer disease (AD) patient [21]. $\mathrm{AD}$ is the leading cause of dementia in the elderly. It is a multifactorial pathology marked with presence of plaques in the brain resulting from the interaction of both genetics and environmental factors. Some studies have implicated MTHFR polymorphism a risk factor for AD [22].

Autism is a neurodevelopmental disorder that is diagnosed in

*Corresponding author: Ahuja YR, Department of Genetics and Molecular Medicine, Vasavi Medical and Research Centre, 6-1-91, Khairatabad, Hyderabad-500004, India, Tel: 23210251, 23323235; E-mail: yrahuja30@gmail.com

Received November 05, 2013; Accepted December 03, 2013; Published December 05, 2013

Citation: Divyakolu S, Tejaswini Y, Thomas W, Thumoju S, et al. (2013) Evaluation of C677T Polymorphism of the Methylenetetrahydrofolate Reductase (MTHFR) Gene in various Neurological Disorders. J Neurol Disord 2: 142. doi:10.4172/23296895.1000142

Copyright: (c) 2013 Divyakolu S, et al. This is an open-access article distributed under the terms of the Creative Commons Attribution License, which permits unrestricted use, distribution, and reproduction in any medium, provided the original author and source are credited. 
Citation: Divyakolu S, Tejaswini Y, Thomas W, Thumoju S, et al. (2013) Evaluation of C677T Polymorphism of the Methylenetetrahydrofolate Reductase (MTHFR) Gene in various Neurological Disorders. J Neurol Disord 2: 142. doi:10.4172/2329-6895.1000142

Page 2 of 4

early paediatric group. Several studies indicate that defects in the folate pathway may play an important role in the pathophysiology of Autism and that MTHFR C677T polymorphism may be an independent risk factor for this neurodevelopmental disorder [23].

James et al. [24] proposed the possibility that gene nutrient interactions associated with abnormal folate metabolism and DNA hypomethylation might increase the risk of maternal meiotic chromosome non disjunction, e.g., Down syndrome (DS), which usually results due to malsegregation (non disjunction) of chromosomes 21. Mothers with the MTHFR677C $\rightarrow$ T mutation had a 2.6-fold higher risk of having a child with Down syndrome than did mothers without the T substitution. Guéant et al. [25] found evidence of an association between total homocysteine (t-Hcys) and MTHFR 677 T with low IQ in DS.

MTHFR C677T mutation has also been associated with neuropsychiatric conditions like schizophrenia-like syndromes, bipolar disorder, Parkinson's disease, and vascular dementia [26]. Hence in this study we have assessed C677T MTHFR polymorphism in three neurological disorders Alzheimer disease (AD), Autism and Down syndrome (DS), and compared it with that in age-matched children and adult controls.

\section{Materials and Methods}

\section{Sample collection}

This case/control study included 100 subjects with different neurological disorders like Alzheimer disease $(n=25)$, Autism $(n=50)$, Down syndrome $(n=25)$, with age-matched controls (100) i.e. 50 adult volunteers with age greater than 50 years and 50 healthy children between the ages of 2 years to 17 years with no neurological defects or family history of $\mathrm{AD}$. The patients of $\mathrm{AD}$ were clinically identified by a neurologist based on the criteria of the National Institute of Neurological and Communicative Disorders and Stroke-Alzheimer's Disease and Related Disorder Association for probable AD (NINCDSADRDA) [27]. DS was diagnosed by the presence of trisomy $21 \mathrm{after}$ karyotyping, while autistic children were selected on the basis of Indian Scale for Autism Assessment (ISAA) which is based on the criteria laid down in "Diagnostic \& Statistical Manual of Mental Disorders-IV" and
Childhood Autism Rating Scale (CARS). The study was approved by Institutional Ethics Committee.

\section{Isolation of genomic DNA}

Blood samples were collected in EDTA vacutainers and DNA was isolated from $300 \mu \mathrm{l}$ of venous blood, by the procedure routinely used in our lab [28]. DNA samples were stored at $-20^{\circ} \mathrm{C}$ till analysis.

\section{Polymerase Chain Reaction (PCR) \& Restriction Fragment Length Polymorphism (RFLP)}

MTHFR genotypes were determined by PCR using specific primers, followed by RFLP and gel analysis as reported earlier by our group $[14,16]$. Hinfl restriction enzyme was used to generate two fragments of $175 \mathrm{bp}$ and 23bp. The PCR products and the enzyme digested PCR products were visualized on $2 \%$ agarose gel stained with ethidium bromide and their band images were analyzed with UVI TECH gel documentation system (Cambridge, UK).

\section{Statistics}

The statistical analysis of data was performed by using 2-way contingency table analysis on stat pages which is available online. Outcomes were assessed with Fisher exact test which was utilized to compare ratios and $\mathrm{p}<0.05$ was accepted as statistically meaningful.

\section{Results}

A total of 100 cases with three neurological disorders and 100 controls participated in the study. The demographic details are mentioned in the Table 1.

The genotype frequencies of CC, CT and TT in controls belonging to both young and old age groups were the same and did not follow the Hardy Weinberg equilibrium. We did not find individuals with TT either in cases or in controls. This is not surprising, given the low incidence of $\mathrm{T}$ allele in Asians as well as the small sample size [29]. Our results were similar to a study done by Kohli et al. [30] who did not find any homozygous TT genotype in DS cases as well as controls.

The frequency of $\mathrm{C}$ and $\mathrm{T}$ alleles were the same in Down syndrome and controls (Figure 1), the T allele was present at a slightly increased

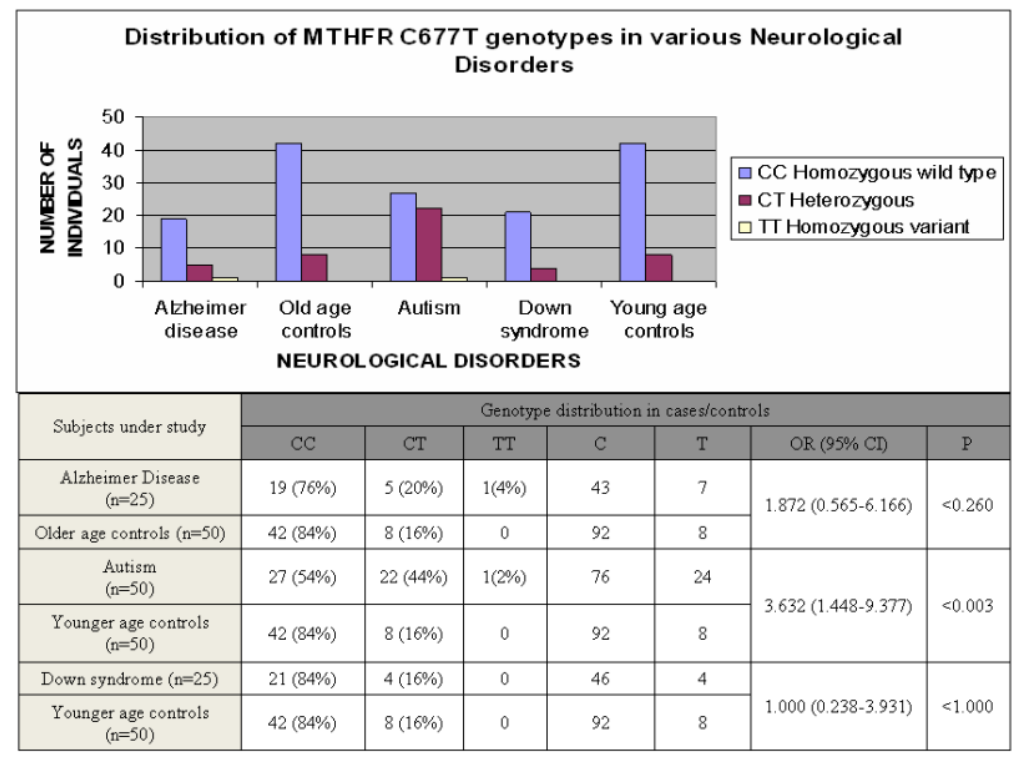

Figure 1: Genotype and allele frequency distribution in cases and controls. 
Citation: Divyakolu S, Tejaswini Y, Thomas W, Thumoju S, et al. (2013) Evaluation of C677T Polymorphism of the Methylenetetrahydrofolate Reductase (MTHFR) Gene in various Neurological Disorders. J Neurol Disord 2: 142. doi:10.4172/2329-6895.1000142

Page 3 of 4

\begin{tabular}{|l|l|l|l|l|l|}
\hline & $\begin{array}{l}\text { Total } \\
\text { cases }\end{array}$ & Male ( & Female $(+)$ & $\begin{array}{l}\text { Age range } \\
\text { (yrs) }\end{array}$ & Mean \pm SD \\
\hline Alzheimer Disease & 25 & 15 & 10 & $52-87$ & $70.2 \pm 10.3$ \\
\hline $\begin{array}{l}\text { Older age } \\
\text { controls>50yrs }\end{array}$ & 50 & 21 & 29 & $50-86$ & $63.42 \pm 8.8$ \\
\hline Autism & 50 & 42 & 8 & $3-17$ & $11.74 \pm 3.7$ \\
\hline Down syndrome & 25 & 16 & 9 & $3-17$ & $6.3 \pm 3.4$ \\
\hline $\begin{array}{l}\text { Younger age } \\
\text { controls<18yrs }\end{array}$ & 50 & 23 & 27 & $2-17$ & $8.76 \pm 3.19$ \\
\hline
\end{tabular}

Table 1: Neurodegenerative cases and controls.

\begin{tabular}{|l|l|l|l|l|}
\hline & & P -value & OR (95\% Cl) & $\mathbf{9 5 \%} \mathbf{C l}$ \\
\hline $\begin{array}{l}\text { Dominant } \\
\text { model }\end{array}$ & TT+CT vs. CC & P $<0.002$ & 4.472 & $1.605-12.799$ \\
\hline $\begin{array}{l}\text { Co-dominant } \\
\text { model }\end{array}$ & CT vs. CC+TT & P $<0.004$ & 4.125 & $1.478-11.817$ \\
\hline $\begin{array}{l}\text { Recessive } \\
\text { model }\end{array}$ & TT vs. CC+CT & P $<1.000$ & 0.490 & $0.017-7.225$ \\
\hline
\end{tabular}

Table 2: Statistical analysis of the Genotype Distribution in Autism cases.

frequency in $\mathrm{AD}$, but this was not statistically significant $(\mathrm{p}<0.260)$

MTHFR C677T allele frequency was found to be higher in autistic children compared with non-autistic children with a 4.47 -fold increased risk for autism [95\% confidence interval (CI): 1.605-12.799) (Table 2). MTHFR 677T allele appears to be a risk factor for autism.

\section{Discussion}

5,10-Methylenetetrahydrofolatereductase, a key enzyme in methionine-homocysteine metabolism, maintains the folate pool between the DNA synthesis and methylation pathways [31-33]. MTHFR C677T ( $r$ 1801133), particularly in the homozygous state, is a risk factor for multifactorial disorders such as cardiovascular disease, spina bifida (NTD), infertility and several other pathologies [34]. C677T polymorphism of the MTHFR gene is important in determining the activity of the enzyme.

One of the neurobehavioral disorders included in our study $\mathrm{AD}$ showed that $20 \%$ of the population was heterozygous (CT), $4 \%$ were homozygous (TT), and $76 \%$ were wild type (CC). $20 \%$ of the cases were heterozygous for this polymorphism (CT) and $\mathrm{T}$ allele was higher in cases compared to controls. However, the data was not statistically significant and this may be because of the small sample size. But earlier studies with a much larger sample (i.e., $n=100$ and $n=140$ ) also did not show association with $\mathrm{AD}$ in Polish and Swedish populations. Our results are in accordance with other studies [21,35] which also failed to find an association between $\mathrm{AD}$ and the $\mathrm{C} / \mathrm{T}$ polymorphism in the MTHFR gene. Results from Japanese, Canadian, Italian and US population were also similar [36-39].

There are several studies which have evaluated the C677T polymorphism in mothers having DS children. Various studies have shown that the C677T polymorphism is a maternal risk factor for DS [40-44]. However, there are few studies in patients with DS per se, as has been evaluated in our present study. Our study does not show association of this polymorphism with either the syndrome or any of its specific clinical characteristics.

Previous studies have reported that perturbations in folate metabolic pathway and polymorphism at C677T of MTHFR gene are associated with autism. There are conflicting reports suggesting both a positive and negative association of MTHFR C677T polymorphism with autism $[45,46]$. In our study, a positive association was observed between MTHFR C677T variant allele and autism risk. Our observation supports the meta-analysis data reported by $\mathrm{Pu}$ et al. [47]. Another study by Mohammad et al. [23] of the MTHFR C677T polymorphism in Indian patients with specific neurological pathologies has indicated that there was significant association with children associated with Autism.

\section{Conclusion}

In conclusion, it can be commented that despite the small sample size the C677T polymorphism of MTHFR plays a role in some complex neurodevelopmental disorders and not in others. Supplementing folic acid B6, B12 in mother or children may be a recommended strategy for management of Autism [48,49].

\section{Acknowledgments}

Financial support from Indian Council of Medical Research (ICMR) is appreciated. We are also thankful to Mr P. Divakar, V. Venkatesh, Kiran Kumar, Rukhsana Sultana and Archana Shiva for literature search.

\section{References}

1. Bottiglieri T, Crellin R, Reynolds EH (1995) Folate and neuropsychiatry. Folate in health and disease, Marcel Dekker, New York.

2. Clarke R, Smith AD, Jobst KA, Refsum H, Sutton L, et al. (1998) Folate, vitamin $\mathrm{B} 12$, and serum total homocysteine levels in confirmed Alzheimer disease. Arch Neurol 55: 1449-1455.

3. Greenblatt JM, Huffman LC, Reiss AL (1994) Folic acid in neurodevelopment and child psychiatry. Prog Neuropsychopharmacol Biol Psychiatry 18: 647-660.

4. Balaghi M, Wagner C (1993) DNA methylation in folate deficiency: use of CpG methylase. Biochem Biophys Res Commun 193: 1184-1190.

5. Pogribny IP, Basnakian AG, Miller BJ, Lopatina NG, Poirier LA, et al. (1995) Breaks in genomic DNA and within the p53 gene are associated with hypomethylation in livers of folate/methyl-deficient rats. Cancer Res 55: 18941901.

6. Fowler BM, Giuliano AR, Piyathilake C, Nour M, Hatch K (1998) Hypomethylation in cervical tissue: is there a correlation with folate status? Cancer Epidemiol Biomarkers Prev 7: 901-906.

7. Jacob RA, Gretz DM, Taylor PC, James SJ, Pogribny IP, et al. (1998) Moderate folate depletion increases plasma homocysteine and decreases lymphocyte DNA methylation in postmenopausal women. J Nutr 128: 1204-1212.

8. Das PM, Singal R (2004) DNA methylation and cancer. J Clin Oncol 22: 4632 4642.

9. Ueland PM, Hustad S, Schneede J, Refsum H, Vollset SE (2001) Biological and clinical implications of the MTHFR C677T polymorphism. Trends Pharmacol Sci 22: 195-201.

10. Goyette P, Sumner JS, Milos R, Duncan AM, Rosenblatt DS, et al. (1994) Human methylenetetrahydrofolate reductase: isolation of cDNA, mapping and mutation identification. Nat Genet 7: 195-200.

11. Sameer AS, Shah ZA, Nissar S, Mudassar S, Siddiqi MA (2011) Risk of colorectal cancer associated with the methylenetetrahydrofolate reductase (MTHFR) C677T polymorphism in the Kashmiri population. Genet Mol Res 10: 1200-1210.

12. Sharp L, Little J (2004) Polymorphisms in genes involved in folate metabolism and colorectal neoplasia: a HuGE review. Am J Epidemiol 159: 423-443.

13. Kang SS, Wong PW (1996) Genetic and nongenetic factors for moderate hyperhomocyst(e)inemia. Atherosclerosis 119: 135-138.

14. Alluri RV, Mohan V, Komandur S, Chawda K, Chaudhuri JR, et al. (2005) MTHFR C677T gene mutation as a risk factor for arterial stroke: a hospital based study. Eur J Neurol 12: 40-44.

15. Movva S, Alluri RV, Venkatasubramanian S, Vedicherla B, Vattam KK, et al. (2011) Association of methylene tetrahydrofolate reductase C677T genotype with type 2 diabetes mellitus patients with and without renal complications. Genet Test Mol Biomarkers 15: 257-261.

16. Vasavi M, Ponnala S, Gujjari K, Boddu P, Bharatula RS, et al. (2006) DNA 
Citation: Divyakolu S, Tejaswini Y, Thomas W, Thumoju S, et al. (2013) Evaluation of C677T Polymorphism of the Methylenetetrahydrofolate Reductase (MTHFR) Gene in various Neurological Disorders. J Neurol Disord 2: 142. doi:10.4172/2329-6895.1000142

methylation in esophageal diseases including cancer: special reference to hMLH1 gene promoter status. Tumori 92: 155-162.

17. Selhub J, Bagley LC, Miller J, Rosenberg IH (2000) B vitamins, homocysteine, and neurocognitive function in the elderly. Am J Clin Nutr 71: 614S-620S.

18. Snowdon DA, Tully CL, Smith CD, Riley KP, Markesbery WR (2000) Serum folate and the severity of atrophy of the neocortex in Alzheimer disease: findings from the Nun study. Am J Clin Nutr 71: 993-998.

19. Miller JW (2000) Homocysteine, Alzheimer's disease, and cognitive function. Nutrition 16: 675-677.

20. Nourhashemi F, Gillette-Guyonnet S, Andrieu S, Ghisolfi A, Ousset PJ, et al. (2000) Alzheimer disease: protective factors. Am J Clin Nutr 71: 643S-649S.

21. Regland B, Blennow K, Germgård T, Koch-Schmidt AC, Gottfries CG (1999) The role of the polymorphic genes apolipoprotein $E$ and methylenetetrahydrofolate reductase in the development of dementia of the Alzheimer type. Dement Geriatr Cogn Disord 10: 245-251.

22. Fernandez LL, Scheibe RM (2005) Is MTHFR polymorphism a risk factor for Alzheimer's disease like APOE? Arq Neuropsiquiatr 63: 1-6.

23. Mohammad NS, Jain JM, Chintakindi KP, Singh RP, Naik U, et al. (2009) Aberrations in folate metabolic pathway and altered susceptibility to autism. Psychiatr Genet 19: 171-176.

24. James SJ, Pogribna M, Pogribny IP, Melnyk S, Hine RJ, et al. (1999) Abnorma folate metabolism and mutation in the methylenetetrahydrofolate reductase gene may be maternal risk factors for Down syndrome. Am J Clin Nutr 70: 495-501.

25. Guéant JL, Anello G, Bosco P, Guéant-Rodríguez RM, Romano A, et al. (2005) Homocysteine and related genetic polymorphisms in Down's syndrome IQ. J Neurol Neurosurg Psychiatry 76: 706-709.

26. Lewis SJ, Lawlor DA, Davey Smith G, Araya R, Timpson N, et al. (2006) The thermolabile variant of MTHFR is associated with depression in the British Women's Heart and Health Study and a meta-analysis. Mol Psychiatry 11: $352-$ 360.

27. McKhann G, Drachman D, Folstein M, Katzman R, Price D, et al. (1984) Clinica diagnosis of Alzheimer's disease: report of the NINCDS-ADRDA Work Group under the auspices of Department of Health and Human Services Task Force on Alzheimer's Disease. Neurology 34: 939-944.

28. Vaidya S, Shaik NA, Latha M, Chava S, Mohiuddin K, et al. (2012) No evidence for the role of somatic mutations and promoter hypermethylation of $\mathrm{FH}$ gene in the tumorigenesis of nonsyndromic uterine leiomyomas. Tumour Biol 33: 1411-1418.

29. Cyril C, Rai P, Chandra N, Gopinath PM, Satyamoorthy K (2009) MTHFR Gene variants C677T, A1298C and association with Down syndrome: A Case-control study from South India. Indian J Hum Genet 15: 60-64.

30. Kohli U, Arora S, Kabra M, Ramakrishnan L, Gulati S, et al. (2008) Prevalence of MTHFR C677T polymorphism in north Indian mothers having babies with Trisomy 21 Down syndrome. Downs Syndr Res Pract 12: 133-137.

31. Rozen R (1997) Genetic predisposition to hyperhomocysteinemia: deficiency of methylenetetrahydrofolate reductase (MTHFR). Thromb Haemost 78: 523-526.

32. Blount BC, Mack MM, Wehr CM, MacGregor JT, Hiatt RA, et al. (1997) Folate deficiency causes uracil misincorporation into human DNA and chromosome breakage: implications for cancer and neuronal damage. Proc Natl Acad Sci U S A 94: 3290-3295

33. Duthie SJ (1999) Folic acid deficiency and cancer: mechanisms of DNA instability. Br Med Bull 55: 578-592.

34. Singh SK, Sah R, Singh I, Raman R (2005) Mutation C677T in the methylenetetrahydrofolate reductase gene is associated with male infertility in an Indian population. Int J Androl 28: 115-119.

35. Religa D, Styczynska M, Peplonska B, Gabryelewicz T, Pfeffer A, et al. (2003) Homocysteine, apolipoproteine $\mathrm{E}$ and methylenetetrahydrofolate reductase in Alzheimer's disease and mild cognitive impairment. Dement Geriatr Cogn Disord 16: 64-70.
36. Postiglione A, Milan G, Ruocco A, Gallotta G, Guiotto G, et al. (2001) Plasma folate, vitamin $B(12)$, and total homocysteine and homozygosity for the C677T mutation of the 5,10-methylene tetrahydrofolate reductase gene in patients with Alzheimer's dementia. A case-control study. Gerontology 47: 324-329.

37. Brunelli T, Bagnoli S, Giusti B, Nacmias B, Pepe G, et al. (2001) The C677T methylenetetrahydrofolate reductase mutation is not associated with Alzheimer's disease. Neurosci Lett 315: 103-105.

38. Prince JA, Feuk L, Sawyer SL, Gottfries J, Ricksten A, et al. (2001) Lack of replication of association findings in complex disease: an analysis of 15 polymorphisms in prior candidate genes for sporadic Alzheimer's disease. Eur J Hum Genet 9: 437-444.

39. Seripa D, Forno GD, Matera MG, Gravina C, Margaglione M, et al. (2003) Methylenetetrahydrofolate reductase and angiotensin converting enzyme gene polymorphisms in two genetically and diagnostically distinct cohort of Alzheimer patients. Neurobiol Aging 24: 933-939.

40. Sadiq MF, Al-Refai EA, Al-Nasser A, Khassawneh M, Al-Batayneh Q (2011) Methylenetetrahydrofolate reductase polymorphisms C677T and A1298C as maternal risk factors for Down syndrome in Jordan. Genet Test Mol Biomarkers 15: $51-57$

41. Wu X, Wang X, Chan Y, Jia S, Luo Y, et al. (2013) Folate metabolism gene polymorphisms MTHFR C677T and A1298C and risk for Down syndrome offspring: a meta-analysis. Eur J Obstet Gynecol Reprod Biol 167: 154-159.

42. Mohanty PK, Kapoor S, Dubey AP, Pandey S, Shah R, et al. (2012) Evaluation of C677T polymorphism of the methylenetetra hydrofolate reductase gene and its association with levels of serum homocysteine, folate, and vitamin B12 as maternal risk factors for Down syndrome. Indian J Hum Genet 18: 285-289.

43. Rai AK, Singh S, Mehta S, Kumar A, Pandey LK, et al. (2006) MTHFR C677T and $\mathrm{A} 1298 \mathrm{C}$ polymorphisms are risk factors for Down's syndrome in Indian mothers. J Hum Genet 51: 278-283.

44. Sheth JJ, Sheth FJ (2003) Gene polymorphism and folate metabolism: a maternal risk factor for Down syndrome. Indian Pediatr 40: 115-123.

45. Boris M, Goldblatt A, Galanko J, James SJ (2004) Association of MTHFR gene Variants with autism. J Am Phys Surg 9: 106-108.

46. dos Santos PA, Longo D, Brandalize AP, Schüler-Faccini L (2010) MTHFR C677T is not a risk factor for autism spectrum disorders in South Brazil. Psychiatr Genet 20: 187-189.

47. Pu D, Shen Y, Wu J (2013) Association between MTHFR Gene Polymorphisms and the Risk of Autism Spectrum Disorders: A Meta-Analysis. Autism Res 6: 384-392.

48. Froster-Iskenius U, Bödeker K, Oepen T, Matthes R, Piper U, et al. (1986) Folic acid treatment in males and females with fragile-(X)-syndrome. Am J Med Genet 23: 273-289.

49. Ramaekers VT, Blau N (2004) Cerebral folate deficiency. Dev Med Child Neurol 46: 843-851. 